\title{
THE ANALYSIS OF MOOD TYPES IN STEVE JOBS' AND BARACK OBAMA'S SPEECHES
}

\section{Slamet Utomo, Rusiana, dan Putri Minarosa}

English Education Department Universitas Muria Kudus

E-mail: slamet.utomo@umk.ac.id

\section{Info Artikel \\ Abstract}

Sejarah Artikel:

Diterima 15 Oktober 2018

Direvisi 22 November 2018

Disetujui 27 November 2018

Keywords:

Mood types, Speech, Steve Jobs, Barack Obama

\begin{abstract}
This research aims to find the differences and similarities of mood types and describe the interpretation of mood types used in the speeches of Steve Jobs as a businessman and Barack Obama as a politician. The design of the research is descriptive qualitative. The result of this research shows that both of the speeches have three types of mood, they are declarative, interrogative and imperative. From the data results, it can be concluded that there are a difference and two similarities of mood types found in the speeches and the interpretation of mood types used in the speeches. At the conclusion of the research, the researchers suggest for students of college and further researcher to analyze mood types in another sources, such as in form of poem or advertisement.
\end{abstract}

\begin{abstract}
Abstrak
Penelitian ini bertujuan untuk menemukan perbedaan dan persamaan jenis mood dan menggambarkan interpretasi tipe mood yang digunakan dalam pidato Steve Jobs sebagai pengusaha dan Barack Obama sebagai politisi. Desain penelitian ini adalah deskriptif kualitatif. Hasil dari penelitian ini menunjukkan bahwa kedua pidato memiliki tiga jenis mood, yaitu deklaratif, interogatif dan imperatif. Dari hasil data, dapat disimpulkan bahwa ada perbedaan dan dua kesamaan tipe suasana hati yang ditemukan dalam pidato dan interpretasi jenis suasana hati yang digunakan dalam pidato. Pada akhir penelitian, para peneliti menyarankan untuk mahasiswa perguruan tinggi dan peneliti lebih lanjut untuk menganalisis jenis suasana hati di sumber lain, seperti dalam bentuk puisi atau iklan.
\end{abstract}


Utomo, S., Rusiana, R., dan Minarosa, $\mathrm{P}$

THE ANALYSIS OF MOOD TYPES IN STEVE JOBS' AND BARACK OBAMA'S SPEECHES

REFLEKSI EDUKATIKA : Jurnal Ilmiah Kependidikan, Nomor 9, Volume 1, Desember 2018, hlm. 6-12

\section{INTRODUCTION}

Nowadays, communication through a speech is an important thing related to the oral transmission of thoughts to audience. By communicating orally, language is a tool used to communicate and interact with people in delivering and expressing thoughts, ideas, concepts, or feelings. In having communication, people have to understand the speaker's language because it is as a means of individual expression. Sometimes, in communication, people can not really understand the message which delivered by the speaker and it causes a misunderstanding. So, without language people can not have a good communication with one another because it is understandable and very functional in communication. Stubbs (1983) said that language has function to get message from others and persuade the addresee of some point of view.

Talking about function of language in communication, Halliday (1994) stated that language is a system for making meaning and he divided it into three main kinds of meaning; ideational, interpersonal, and textual meaning. This research emphasizes to the interpersonal meaning that is about relationship with others and our attitude to each other. It focuses on the interactivity of language and it can be realised through selections from the system of mood, especially used in the speech. According to Halliday in Matthiessen (2004), there are three general types of mood: declarative, interrogative, and imperative.

Related to mood types analysis, the researchers are interested in analysing the speeches of Steve Jobs and Barack Obama who have different profession, Steve Jobs is as a great bussinessman who leads the company of Apple Inc and Pixar Animation, and Barack Obama is as an American politician. From the different profession of the speakers, their speeches are assumed having different contents and meanings caught by the audience and they also contain of various mood types.
For the previous research is in the article of Ye (2010) in analysing the interpersonal metafunction of Barack Obama's speech, showed that the mood type that was dominant used in the speech was declarative mood because the political speech carried of a political mission that was functioned as statements to give as much as possible information and demand services to the audience in his presidential election campaign, and also to offer certain messages such as making promises and inspiring people by showing his political attitude and assumpsion.

Taking insight from the background above, this research takes two speeches which are from Steve Jobs and Barack Obama, and poses these questions: What What are the differences and the similarities of the mood types used in Steve Jobs' and Barack Obama's speeches? What is the interpretation of the mood types used in the speeches of Steve Jobs and Barack Obama?

\section{RESEARCH METHOD}

The design of the research is descriptive qualitative. The result of this research shows that both of the speeches have three types of mood, they are declarative, interrogative and imperative.

\section{FINDING AND DISCUSSION FINDING}

In classifiying the type of mood, the researchersidentified the subject and finite in every clause in the speech scripts of Steve Jobs and Barack Obama. The classification was based on the order of subject and finite. While the order of mood is subject and finite, the mood is declarative. While the order of mood is finite and subject, the mood is interrogative. If the order of mood is finite only, subject only, or there is no mood elements, it belongs to imperative mood.

The following is the table of the number of mood types found in the speech scripts of Steve Jobs and Barack Obama.

Table 1. The Number and the Percentage of Mood Types Found in the Speech Scripts of Steve Jobs and Barack Obama.

\begin{tabular}{|c|c|c|c|}
\hline \multirow{2}{*}{ Mood Types } & \multicolumn{2}{|c|}{ Clauses } & \multirow{2}{*}{ Total } \\
\cline { 2 - 4 } & Steve Jobs & Barack Obama & 658 \\
\hline \multirow{2}{*}{ Declarative mood } & 302 & 356 & $93,7 \%$ \\
\cline { 2 - 4 } & $93 \%$ & $94,4 \%$ & 12 \\
\hline \multirow{2}{*}{ Interrogative mood } & 4 & 8 & $1,7 \%$ \\
\cline { 2 - 4 } & $1,2 \%$ & $2,1 \%$ & 32 \\
\hline \multirow{2}{*}{ Imperative mood } & 19 & $3,5 \%$ & $4,6 \%$ \\
\hline TOTAL & $5,8 \%$ & 377 & 702 \\
\hline
\end{tabular}


Utomo, S., Rusiana, R., dan Minarosa, P

THE ANALYSIS OF MOOD TYPES IN STEVE JOBS' AND BARACK OBAMA'S SPEECHES

REFLEKSI EDUKATIKA : Jurnal Ilmiah Kependidikan, Nomor 9, Volume 1, Desember 2018, hlm. 6-12

Based on table 1, it could be seen that the speech scripts of Steve Jobs and Barack Obama have completed mood types that consist of declarative, interrogative, and imperative mood. In the speech script of Steve Jobs, it has 325 clauses which consist of 302 clauses of declarative mood which are marked in form of statement clauses, 4 clauses of interrogative mood in the clauses of question, and 19 clauses of imperative mood in the clauses of command. While, in the speech script of Barack Obama, it contains of 377 clauses which consist of 356 clauses of declarative mood in form of statement clauses, 8 clauses of interrogative mood which are signed in form of question clauses, and 13 clauses of imperative mood which are in form of command clauses.

\section{DISCUSSION}

Discussion presents the mood types found in the speeches of Steve Jobs and Barack Obama. It is discussed with some examples and brief explanation of each analysis. From the total number of mood types, the researchers got differences and similarities of mood types used in the speeches of Steve Jobs and Barack Obama.

\section{The Differences of Mood Types Found in the Speech Scripts of Steve Jobs and Barack Obama}

Based on the different profession of the speaker, firstly the researchers would explain that Steve Jobs is a businessman which proven by his profession as a founder of Apple Inc and by a sentence of "We worked hard, and in 10 years Apple had grown ....... with over 4,000 employees", it told about his struggle in starting his business of Apple with his friend, Woz, in his parents' garage and they made it develop with many employees. Then, Barack Obama is a politician which proven by his profession as a 44th President of America and by a sentence of "I have talked a lot about your government's responsibility .... where the students are not getting the opportunities that they deserve", it told that he tried to fix all the government's problems which made people especially students difficult in making their dreams come true. From the explanation above, the researchers did not find many differences of mood types in both of the speeches, but they have a difference which seen from the number of mood types found in their speeches.
Steve Jobs produces 325 clauses and Barack Obama produces 377 clauses in each of their speeches. From the number of clauses, it shows that a politician tells something more in a speech than a businessman does which supported by the use of declarative mood found in their speeches, there are 302 clauses (93\%) produced by Steve Jobs and 356 clauses $(94,4 \%)$ are produced by Barack Obama.

Excerpt 1:

- $\quad$ Today I want to tell you three stories from my life. (Steve Jobs)

- I am here because I want to talk with you about your education. (Barack Obama)

In those examples, they are statements that belong to declarative mood which used by the speaker (Steve Jobs and Barack Obama) to tell about their aim in delivering a speech. Both of the clauses were delivered in the beginning of the speech to introduce what they were going to discuss. In that moment, Steve Jobs would like to tell about three stories of his hard life in doing his education, starting his business, untill facing his cancer. While in the speech of Barack Obama, he wanted to tell the audience/students that he was going to discuss about education especially for the responsibility of each student in achieving their dreams.

Concerning with the number of the use of interrogative mood, it is stated that a businessman does not interact a lot with the audience than a politician does which proven by the clauses produced. Steve Jobs produces only 4 clauses $(1,2 \%)$ and Barack Obama produces more with 8 clauses $(2,1 \%)$ of interrogative mood.

Except 2:

(1) Do you want him?
(Steve Jobs)
(2) So why did I drop out?
(3) How can get fired from a company you
started?
(1) How is everybody doing today?
(Barack Obama)
(2) (Do) you want to be a doctor, or a $t$
teacher, or a police officer?
(3) (Do) you want to be a nurse, or an
architect, a lawyer or a member of our
military?
Those clauses are questions in form which used by the speakers (Steve Jobs and Barack Obama) to keep their communication going with the audience and in speech they do not require answers. Here, Steve Jobs' first question was a direct sentence which used by 
Utomo, S., Rusiana, R., dan Minarosa, $\mathrm{P}$

THE ANALYSIS OF MOOD TYPES IN STEVE JOBS' AND BARACK OBAMA'S SPEECHES

REFLEKSI EDUKATIKA : Jurnal Ilmiah Kependidikan, Nomor 9, Volume 1, Desember 2018, hlm. 6-12

his biological parents when they called his adoptive parents and asked whether they wanted or not to adopt him. Then, for the second and third questions, he wanted to tell about the reason why he could be dropped out from his college and got fired from his own company by giving question to begin his story. While the first question of Barack Obama told that he wanted to greet the audience by asking how their life were in the beginning of his speech. Next, the second and third questions are used by Barack Obama to get the audience's attention and try to make them think about what they want to be for their future.

On the other hand, based on the result, a businessman more often provides command than a politician does. It is supported by the use of imperative mood which showed from the number of the clauses produced. Steve Jobs produces 19 clauses $(5,8 \%)$ and Barack Obama produces 13 clauses $(3,5 \%)$ of imperative mood. Excerpt 3:

- $\quad$ Let me give you one example. (Steve Jobs)

- Go ahead. And have a seat.

(Barack Obama)

From the examples above, the speakers (Steve Jobs and Barack Obama) gave command clauses by asking the audience to do something and also by giving an understanding. Using a word 'Let me', Steve Jobs wanted to ask a permission to give the audience one example of his opportunities to learn about calligraphy after he had dropped out from his college. While the command of Barack Obama 'Go ahead' and 'and have a seat' delivered in the beginning of the speech to ask the audience to continue their business first and invite them to sit comfortably in order to make them pay attention to his speech well.

From the explanation above, the researchers conclude that Steve Jobs as a businessman and Barack Obama as a politician have a significant difference which can be seen from the use of interrogative and imperative mood. Steve Jobs as a businessman is more motivational because he often provides command clauses to give motivation to the audience, while Barack Obama as a politician is more interactive because he more often produces question clauses to keep interaction going with the audience.

The Similarities of Mood Types Found in the Speech Scripts of Steve Jobs and Barack Obama
After finding the difference, the researchers also found two similarities of mood types used in the speeches of Steve Jobs and Barack Obama. They are about the same dominant mood type and the same order of the use of mood types which are from the use of declarative mood, imperative mood, and interrogative mood.

The first similarity found in the speeches is about the dominant mood type. Both of the speeches have the same dominant mood type, it is declarative mood because it has highest number among the other mood types. Steve Jobs produces $93 \%$ and Barack Obama produces $94,4 \%$ of declarative mood which showed by many statements in the speeches. This finding is in line with the previous research, Ye (2010). This research found that declarative mood is the dominant mood type produced by Barack Obama in his victory speech. In his speech, he congratulated his Republican rival John McCain and his running mate Sarah Palin for their achievements in the presidential campaign and also praised his campaign team as one of the best in history even thanked his family for their support during the presidential campaign.

The second similarity of mood types used in the speeches is about the order of the use of mood types. According to the percentage number of mood types, both of the speeches have the same order from declarative, imperative, and interrogative mood. The researchers found that declarative mood is a great majority in both of the speeches with 93\% (Steve Jobs) and 94,4\% (Barack Obama). It is proven by many statements which produced by the speakers, such as 'And here I was spending all of the money' and 'I lived in Indonesia for a few years'. Those clauses are statements which used by the speakers to tell the facts about their experience in past they faced before they became successful people right now. The next order is imperative mood which proven by command used by the speakers functioned to ask, invite or give instruction to the audience to do something. Steve Jobs produces 5,8\% and Barack Obama produces 3,5\% of imperative mood. They used some commands in clauses such as 'Do not lose faith' and 'And do everything'. Those clauses are the commands used by the speakers to ask something to do to the audience in order to make them enthusiastic in facing life and achieving their dreams. The last order is interrogative mood which marked by question in form that used to ask or keep 
Utomo, S., Rusiana, R., dan Minarosa, $\mathrm{P}$

THE ANALYSIS OF MOOD TYPES IN STEVE JOBS' AND BARACK OBAMA'S SPEECHES

REFLEKSI EDUKATIKA : Jurnal Ilmiah Kependidikan, Nomor 9, Volume 1, Desember 2018, hlm. 6-12

interaction during the speech. Steve Jobs produces $1,2 \%$ and Barack Obama produces $2,1 \%$ of interrogative mood, which proven by some clauses as 'How can you get fired from a company you started?' and 'What will a President say about what all of you did for this country?'. Those clauses are questions in form which are in self-questioning clause requiring no answer. Here, they used the questions to have interaction with the audience and make them think about the answer for themselves. This finding is supported by Yang (2017) which showed that in Barack Obama's Inaugural Address had the same order of the use of mood types. In this research, declarative mood was in the first place which in form of statements that functioned to give as much as possible information to the audience with which he succeded in recalling his presidential election campaign, expressing his gratitude to his supporter, making promises and inspiring the audience to go through the difficulties with the whole nation. In the second place was imperative mood which could appeal the audience to follow the addressee's instruction. While the last order was interrogative mood, in this speech there was no interrogative mood.

Based on the similarities, the researchers state that the speeches of Steve Jobs as a businessman and Barack Obama as a politician have the same main function to give and tell information and facts which proven by the use of declarative mood as the dominant mood type.

\section{The Interpretation of Mood Types Used in the Speech Scripts of Steve Jobs and Barack Obama}

\section{Declarative Mood}

Declarative mood used in the speeches are 302 clauses in Steve Jobs' speech and 356 clauses are in Barack Obama's speech. In these speeches, many clauses belong to declarative mood. These are the examples of declarative clause:

After six months, I could not see the value in it. (Steve Jobs)

- $\quad$ My father left my family.

(Barack Obama)

Based on the examples above, it proves that declarative mood is the clauses in form of statements which tell or give an information or fact. For the first clause, Steve Jobs shared about his education which he took in university level. After six months studied there he thought that he did not get anything from it, he felt that it was useless for his life, moreover he also felt as a burden for his parents in spending their money to study in the expensive university. The second clause told about the life of Barack Obama who left by his father when he was two years old and he had to see his mother became a single mom who struggled alone to raise him, worked hard to get money for their daily life, it was so distressed for him.

\section{Imperative Mood}

Imperative mood used in the speeches are 19 clauses in Steve Jobs' and 13 clauses are in Barack Obama's. Here are some clauses of imperative mood used in the speeches:

\section{- Keep looking. Do not settle.}

(Steve Jobs)

- Give yourselves a big round applause. (Barack Obama)

From the examples above, they belong to the clauses of imperative mood. They are in commands form which functioned to ask or give instruction and to give motivation to the audience. Steve Jobs as a businessman used these clauses of command to motivate the audience to always try and not easy to be satisfied of the things they got and always interested to do something for making their lives more precious. While for the next clause, Barack Obama as a politician used this command in the beginning of speech to give instruction to the audience to give big applause of the outstanding host of Wakefield High School which provided time and place for the event held with all students of America. In this event, Barack Obama had an ocassion to deliver his speech which told about education and inspiration of his life story and even giving motivation for them to achieve goals by studying hard.

\section{Interrogative Mood}

There are interrogative mood produced in both of the speeches. Steve Jobs uses 4 clauses and Barack Obama uses 8 clauses of interrogative mood. The followings are the examples of interrogative mood used in the speeches:

- How can you get fired from a company you started?

- What discoveries will you make?

Those examples above belong to interrogative mood which are questions in form. In a speech, kind of question is in fact of selfquestioning that does not need answer from the 
Utomo, S., Rusiana, R., dan Minarosa, $\mathrm{P}$

THE ANALYSIS OF MOOD TYPES IN STEVE JOBS' AND BARACK OBAMA'S SPEECHES

REFLEKSI EDUKATIKA : Jurnal Ilmiah Kependidikan, Nomor 9, Volume 1, Desember 2018, hlm. 6-12

audience. They have function to keep the interaction and communication going between the speaker and the audience. The researchers state that question form in speech can make the audience active in thinking and imagining the answer of the question for themselves. Steve Jobs presented the question to make the audience think why it could happen to the founder of the company itself. He had built and developed the company with his hard work and suddenly he had to get fired only because of the different vission with the directors. The question clause used by Barack Obama aimed to make the audience realize that they had to try making a new discovery for their country. Before asking question, Barack Obama introduced some successful people who made a creation and discovery for the country even for the world. He told about J.K Rowling who wrote her first book of Harry Potter which was rejected 12 times and finally with her hard work it could be published. He told about the successful people because he wanted to tell that we would never get a succeed if we never failed, so with getting failed we could make it as a lesson to do better, better, and better.

After describing the findings of the research, the researchers interpret that the speeches of Steve Jobs as a businessman and Barack Obama as a politician have three types of mood, they are declarative, imperative and interrogative mood. The use of declarative mood functions to give and tell more information and fact that proven by many statements produced in the speeches which has the highest percentage number among the other mood types. Furthermore, their speeches also contain of imperative mood which functions to ask to do something and motivate the audience by using clauses of command, and they contain of interrogative mood which functions to keep communication going during the speech and make the audience active in thinking the answer of the question for themselves which delivered by the speaker.

\section{CONCLUSION AND SUGGESTION}

This research takes the speeches of Steve Jobs and Barack Obama as samples to analyze the mood types found in the public speeches of a businessman and a politician. The data result shows that there are a difference and two similarities of mood types used in their speeches. A businessman is more motivational than a politician which proven by the use of imperative mood, Steve Jobs provides higher number of imperative mood with 5,8\% than Barack Obama with 3,5\%. Then, from the use of interrogative mood, it shows that a politician is more interactive than a politician. Steve Jobs produces less number of interrogative mood with 1,2\% than Barack Obama with 2,1\%. For the similarities, both of the speeches have the same dominant mood type which has the highest percentage number among the other mood types, it is declarative mood. The dominant mood type used in the speeches indicates that the speeches have main function to tell or give information and facts to the audience, followed by asking and giving instruction and motivation, and keeping interaction going between the speaker and audience during the speech.

This research is still lack in some theory, so the researchers suggest that the readers or further researchers can try to analyze mood types not only in speech but also in another sources, such as poem or advertisement.

\section{REFERENCES}

Andi. 2016. Biografi Singkat Steve Jobs, Si Jenius Bisnis Pendiri Apple Inc. Retrieved from https://www.google.co.id/amp/www.ruan gfreelance.com/biografi-singkat-stevejobs-si-jenius-bisnis-pendiri-appleinc/amp/.

Dhiah, N.A. 2011. Interpersonal Meaning of Barack Obama's Speech at University of Indonesia: The Study of Barack Obama's Attitudes and Judgements Towards Indonesia. Skripsi. Semarang: University of Semarang.

Eggins, S. 1994. An Introduction to Systemic Functional Linguistics. London: Pinter Publisher Ltd.

\begin{tabular}{l} 
Functional 2004. An $\begin{array}{c}\text { Introduction to Systemic } \\
\text { Linguistics. }\end{array}$ \\
\hline Lontinuum.
\end{tabular}

Eggins, S. S, D. 1997. Analysing Casual Conversation. London: Cassel.

Gerot, L. W, P. 1995. Making Senses of Functional Grammar. Second Edition. Sydney: Gerd Stabler. 
Utomo, S., Rusiana, R., dan Minarosa, $\mathrm{P}$

THE ANALYSIS OF MOOD TYPES IN STEVE JOBS' AND BARACK OBAMA'S SPEECHES

REFLEKSI EDUKATIKA : Jurnal Ilmiah Kependidikan, Nomor 9, Volume 1, Desember 2018, hlm. 6-12

Halliday, M.A.K. 1985. An Introduction to Functional Grammar. London: Edward Arnold.

1994. An Introduction to Functional Grammar. Second Edition. London: Edward Arnold.

Halliday, M.A.K. Matthiessen. 2004. An Introduction to Functional Grammar. Third Edition. London: Edward Arnold.

Liping, C. 2017. Mood, Modality, and Polarity Analysis of Winston S. Churchill's Speech on Hitler's Invasion of the U.S.S.R. Advances in Social Sciences Research Journal, 4(1) 195-202.

Noor, et al. 2015. Systemic Functional Linguistics Mood Analysis of the Last Address of the Holy Prophet (PBUH). International Journal of Language and Linguistics, Vol 3, 1-9.

Nugroho, S.M. 2013. An Analysis of Modality in the Script of Anthony Robbins' Motivation Speech "Why We Do What We Do". Skripsi. Kudus: University of Muria Kudus.

Permata, A.F.A.A. S. 2015. Mood Types Analysis of Teaching and Learning Process in Immersion Class of Theresiana 1 Senior High School. Skripsi. Semarang: University of Dian Nuswantoro.
President Obama Makes Historic Speech to America's Students. 2017. Retrieved from https://www.youtube.com/5a5VSkkdpB4 , accessed on January $27^{\text {th }}, 2017$.

Setiadi, T. 2014. Biografi Singkat Barack Obama. Retrieved from http://www.tedisetiadi.com/2014/03/biog rafi-singkat-barack-obama.html?m=1, accessed on March 13 ${ }^{\text {rd }}, 2014$.

Schreiber, L. H. 2013. Public Speaking: Virtual Text. San Francisco: Creative Commons Attribution.

Steve Jobs: Stanford Commencement Speech. 2017. Retrieved from https://www.youtube.comUF8uR6Z6KL c, accessed on March 27 $7^{\text {th }}, 2017$.

Thompson, G. 1996. Introducing Functional Grammar. London: Edward Arnold.

Yang, H. 2017. The Interpersonal Metafunction Analysis of Barack Obama's Inaugural Address. International Journal of Languages, Literature and Linguistics, 3(1) 27-31.

Ye, Ruijuan. 2010. The Interpersonal Metafunction Analysis of Barack Obama's Victory Speech. English Language Teacher, 3 (2), pp 146-151. 